\title{
Andrea F. De Carlo*
}

iD https://orcid.org/0000-0001-9116-8308

\section{'Honor the great poet' The Józef Ignacy Kraszewski's contribution to the development of Polish Dante studies}

\section{I}

In the remarkable artistic legacy of Józef Ignacy Kraszewski (1812-1887), which mainly characterized his activity as a novelist, a publicist and a literary critic, his contribution to Dante studies must be mentioned. The Soviet critic Ivan K. Gorskij also considered the Polish writer to be one of the founders of the contemporary Polish Dante studies'. According to the expert in Polish literature the relationship between Kraszewski and Dante may be summed up in three key stages: the impact of Dante on the works of Kraszewski²; the writer's contribution to Polish Dante studies with his lessons of 1867 published two years after; finally his translation of the Divine Comedy ${ }^{3}$. At this point, we shall focus on analysis of his lessons on

* Prof. dr, 'L'Orientale' University of Naples, Department of Literary, Linguistic and Comparative Studies, Santa Maria Porta Coeli Palace, via Duomo, 219, 80138 Naples, Italy, afdcarlo@unior.it

1 I. K. Gorskij, Крашевскийи Данте, “Дантовские чтения" 1968, р. 33.

2 For a deeper investigation of the issue, please consult a part of the article by: A.F. De Carlo, Między piekłem a niebem. Postrzeganie Boskiej Komedii Dantego przez Zygmunta Krasińskiego i Józefa lgnacego Kraszewskiego, in: Krasiński i Kraszewski wobec europejskiego romantyzmu i dylematów XIX wieku. W dwustulecie urodzin pisarzy, M. Junkiert, W. Ratajczak, T. Sobieraj (eds.), Wyd. Poznańskiego Towarzystwa Przyjaciół Nauk, Poznań 2016, pp. 33-45.

3 See also: A.F. De Carlo, O specyfice języka J.I. Kraszewskiego w rękopisie zawierająym tłumaczenie Boskiej Komedii Dantego, in: Kraszewski i wiek XIX. Studia, idea and layout J. Ławski; A. Janicka, K. Czajkowski, P. Kuciński (eds.), Książnica Podlaska im. Łukasza Górnickiego, Katedra Badań Filologicznych „Wschód-Zachód”, Wydział Filologiczny Uniwersytetu w Białymstoku, Białystok 2014, pp. 291-309; idem, La Divina Commedia nella Polonia del XIX secolo. Le prime traduzioni polacche del poema dantesco a confronto, in: II Dante dei moderni. La Commedia 
Dante's poem which were published under the title Dante. Studja nad Komedja Boska (Dante. Studies on the Divine Comedy, 1869) ${ }^{4}$.

When Kraszewski was writing his essay on Commedia, Poland only knew the full publication of Dante's poem for a short time thanks to the translation by Julian Korsak (1860) and Polish Dante studies was taking its first steps compared to other countries such as France, England and neighboring Germany. Kraszewski, embittered, was looking right at the rich German tradition of Dante studies which even then boasted the works of Karl Witte (1800-1883) or the artistic tradition of Commedia translated by Philalethes (under the pseudonym of John, the King of Saxony,1801-1873), published in $1867^{5}$. Thus, the lack of knowledge of Commedia and its author which affected Polish soil those days, was recorded by the author of Stara baśń (Kraszewski - ŁJB) during his lessons on the divine poem:

[...] there has been no talk about Dante in Poland for a while. [...] In the meantime, until the 19th century Dante remained almost completely unknown, and while other peoples adopted this masterpiece [The Divine Comedy, ADC] as a common prerogative of Christianity, making efforts to explore its spirit, to analyze its beauty as well as to uncover its mysteries and gathering the entire collections of books that constitute already Dante's literature; at the same time, we barely learned the name of the great poet ${ }^{6}$.

If taking into account that about twenty translations (three old and newer ones) of the Divine Comedy were published until 1869 in Germany, Kraszewski's words of sadness written in his lectures became more than understandable: 'These days one might put together the whole and relevant library of Dante's books in all the

dall'Ottocento a oggi. Saggi critici, a cura di J. Szymanowska, I. Napiórkowska, LoGisma, Firenze 2017, pp. 125-144.

4 On this issue see also: O. Płaszczewska, „Onorate l'altissimo poeta”: Józef lgnacy Kraszewski jako komentator Dantego, in: Kraszewski: poeta i światy, T. Budrewicz, E. Ihnatowicz, E. Owczarz (eds.), Wyd. UMK, Toruń 2012, pp. 191-203.

5 While exploring Dante's works in the years 1839-1853, John, the King of Saxony, could rely on the skilled assistance of Julius Petzholdt (1812-1891), his librarian and bibliographer, who was author of important references and studies on Dante.

6 '[...] w Polsce długo jest głucho o Dancie. [...] Tymczasem aż do XIX wieku Dante pozostaje nam prawie zupełnie nieznanym, i gdy inne narody jak wspólną własność chrześciaństwa przyswajają sobie to arcydzieło, usiłując wniknąć w jego ducha, badają piękności i rozsłaniają tajemnice, gdy gdzieindziéj całe księgozbiory stanowi już literatura Dantejska - my ledwie się jeszcze uczemy imienia wieszcza' (J.I. Kraszewski, Dante. Studja nad Komedja Bozką przez J.I. Kraszewskiego, 'Roczniki Towarzystwa Przyjaciół Nauk Poznańskiego' 1869, vol. V, p. 98). [Here and onwards the translations from Polish, unless otherwise stated, are provided by the translator - ŁJB]. 
languages of the world except for ours (Polish - ŁJB), which appears to be the poorest. The laziness of our mind reveals itself."

\section{II}

It is common knowledge that in 1851 Kraszewski had expressed the desire to obtain the position of professor at the Jagiellonian University in Cracow. His program of studies was originally supposed to include the whole term of classes such as a comprehensive introduction to Christian medieval poetry, life and works of Dante as well as the knowledge of the epoch which the great Polish poet lived in ${ }^{8}$.

However, Kraszewski failed to obtain his tenured professorship at the university of Cracow, but in return in 1867 he was invited by Towarzystwo Wzajemnej Pomocy Uczniów Uniwersytetu Jagiellońskiego ('Association for Mutual Assistance for Students of the Jagiellonian University') to hold four public lectures on the Divine Comedy.

The speeches of Kraszewski were subsequently published in 'Rocznik Towarzystwa Przyjaciół Nauk w Poznaniu' in 1869 under the aforementioned title: Dante. Studja nad Komedja Boska. Later that year the collective volume Kłosy i Kwiaty ${ }^{9}$ was released and finally, a year after, the lectures of Kraszewski were translated into German by Szczepan Bohdanowicz ${ }^{10}$.

Critics regarded the lectures of Kraszewski as a comprehensive and valuable monographic work on the Florentine poet written ever until then in Polish"1. The content was perceived as a great introduction to reading the poem where the author presented the historical background of the era by introducing and analyzing Dante as a man, a politician and an ingenious poet. Kraszewski showed an in-depth knowledge of the author and his works expressed in both detailed descriptions of the life of the Florentine master and a pertinent analysis of the Commedia ${ }^{12}$.

7 'Złożyćby dziś można całą a znaczną biblijotekę Dantejską we wszystkich świata językach, oprócz może naszego, któryby najuboższym się okazał. Lenistwo naszego ducha i w tém się objawia' (J.I. Kraszewski, Dante. Studja..., p. 168).

8 Cf. J.I. Kraszewski, Pamiętniki, W. Danek (ed.), Ossolineum, Wrocław 1972², pp. 286 and 292.

9 In Kłosy i Kwiaty an excerpt from Kraszewski's translation is quoted only: Raj XVII, vv. 55-69 (J.I. Kraszewski, Dante (z odczytów J.I. Kraszewskiego 1867 r.), in: Kłosy i kwiaty. Ksiq̨żka zbiorowa w Krakowie, W Drukarni W. Kirchmayera, Cracow 1869, pp. 88-89).

10 Dante. Vorlesungen ueber die Goettliche Komoedie gehalten in Krakau und Lemberg 1867 von J.I. Kraszewski. Ins Deutsche uebertragen von S. Bohdanowicz, Druk und Verlag von J. I. Kraszewski, Dresden 1870.

11 B. Biliński, Roma antica e moderna nelle opere di Giuseppe Ignazio Kraszewski, Wyd. PAN, Wrocław-Warsaw-Cracow 1965, p. 16.

12 Cf. H. Bursztyńska, Kraszewski Orzeszkowa Sienkiewicz. Studia i szkice, Wyd. Naukowe WSP, Cracow 1998, p. 45. 
The lectures delivered by Kraszewski may be classified as part of numerous events which happened from 1865 onwards which coincided with the year of Dante's 600th anniversary of birthday. Moreover, in 1867 the city of Cracow decided to celebrate, with the voice of Kraszewski who was the expression of the relationships that linked Poles with the Italian genius, the year of anniversary. The issue of these lectures accompanied with other numerous accounts published in the European press, whose original aim was to make Poles more familiar with the Commedia and its author.

The record of Kraszewski's presence in Cracow as well as of his lectures was published on April 25, 1867 in the journals 'Czas' and 'Gazeta Polska' issued in Warsaw; the article of the latter contained bibliographic references on Dante edited by Karol Estreicher ${ }^{13}$. Later on, an extensive rundown on the facts was given by Michał Frąckiewicz in his essay published in Cracow in: Józef Ignacy Kraszewski w Krakowie $i$ we Lwowie w r. 1867 I odczyty jego o Dantem. Wspomnienia z przeszłości w setna rocznice urodzin (Józef Ignacy Kraszewski in Cracow and in Lviv in 1867 and his lectures on Dante. The memories of the past on the centenary of birth).

The stay of Kraszewski in Cracow lasted from April 27 to May 7, 1867: during those ten days, the writer managed to dedicate himself to his projects and visited the Jagiellonian Library where he collected material for his three-volume work Polska w czasie trzech rozbiorów 1772-1799 r. Studia do history ducha i obyczaju (Poland of the time of the three partitions 1772-1799. The studies on history of the spirit and tradition $)^{14}$.

The lectures were held, as it was customary at the time, at the premises of 'The Association of Science and Humanities' in Sławkowska Street (today housing the Academy of Skills) on April 29 and continued on May 1, 4 and 6. The audience was numerous during all four lectures which attracted a huge interest even though the name of Dante was barely known.

In his record, Frąckiewicz thoroughly reported the course of events ${ }^{15}$ : the first lecture was held on April 29, 1867 and provided a general introduction to the poem; Kraszewski presented the life of Dante and made some remarks on his education, the uniqueness of his genius and exile years. The second lecture took place on Wednesday of May 1: the speaker delivered an address on the final years of Dante's life by mentioning biographers and commentators of the divine poet;

13 The title of the article published in 'Gazeta Polska' (n. 90) April 18, 1867, was Przekłady Danta (cf. M. Frąckiewicz, Józef Ignacy Kraszewski w Krakowie i we Lwowie w r. 1867 i odczyty jego o Dantem. Wspomnienia z przeszłości w setna rocznicę urodzin, Nakładem Autora, Cracow 1912, p. 11).

14 Ivi, p. 12.

15 Frąckiewicz offers a comprehensive summary of Kraszewski's lectures; moreover, it should be specified that passages quoted by the critic are taken from the essay Dante. Studja nad Komedja Boska, however typos or even omissions of the whole lines occurred. 
subsequently, he moved on to presenting the structure of the poem. In the third lecture, which was held on May 4, Kraszewski gave a detailed summary of the contents of the Commedia with particular attention to Purgatory; he highlighted selected episodes of the second canticle referring to numerous extracts of its translation ${ }^{16}$. Finally, on Monday of May 6, 1867 the fourth and last lecture took place, where the author proposed a summary and a brief analysis of the Paradise, concluding with the reading of extensive excerpts of the poem ${ }^{17}$.

The same day at evening Kraszewski left for Lviv where he reached the next day. That is where the author of Stara baśn ('An Ancient Tale') had been invited to by a student patriotic organization known as Czytelnia Akademicka ('Academic Study Room') founded in 1867 on the model of the similar organization born earlier at the Jagiellonian University. The lives of young students in Lviv of that time was strongly germanized, which provoked revitalization of national languages and literary traditions.

The author remained in Lviv for about ten days delivering his lectures in the hall of the city council on May 8, 11, 12 and 15 respectively. Kraszewski repeated what he previously said in $\mathrm{Cracow}^{18}$ except that participation of Lviv's audience was smaller. That might have been, most likely, a consequence of the publication of Rachunki (Accounts) ${ }^{19}$ released earlier that year which brought about a widespread sentiment of acrimony towards Kraszewski. Nevertheless, the distinguished novelist and his lectures on Dante were welcomed with great enthusiasm ${ }^{20}$ as we can deduce from the article of May 14, 1867 appeared on 'Dziennik Literacki' (Literary Journal), whose editor Juliusz Starkel greeted Kraszewski's presence in Lviv with warm cordiality and deep respect ${ }^{21}$.

\section{III}

Studja nad Komedja Boska (Studies on the 'Divine Comedy') consist of three essential parts: introduction, theme and content analysis and conclusion. In the preface, the author presents selected stages of Dante's life where he outlines the personality

16 M. Frąckiewicz, op. cit., p. 38.

17 Ivi, p. 44.

18 Frąckiewicz reports the ticket fare: '2 zł. 50 ct.' (ivi, p. 52).

19 Rachunki was published by the author between 1866 and 1870 where he shed light on all the phenomena of cultural, political and social life of the country, calling for the day of reckoning, particularly, the landed gentry which he himself came from. He attacked clerical-feudal alliance, spotted the intrigues and defeated ultramontanes (cf. B. Biliński, Incontri polacco-italiani a Porta Pia: J.I. Kraszewski, W. Kulczycki, M. Konopnicka. Nel centenario di Roma capitale d'Italia 1870-1970, Wyd. PAN, Wrocław-Warsaw-Cracow-Gdańsk 1971, p. 25).

20 M. Frąckiewicz, op. cit., p. 53.

21 Ivi, p. 51. 
of the Italian genius, his poetical sensibility as well as the most important events that marked his life: love, politics and exile. This is where Kraszewski formulated the thesis on the exceptionality of Dante which he subsequently proved and motivated in the process of argumentation. That overall presentation is followed by the core part of the elaborate which comes with an extensive summary of the Divine Comedy, accompanied with a thorough text analysis. In conclusion, the author largely focuses on the reception of Dante in a wider European context as well as in the Polish one, in particular.

Kraszewski, adopting the opinion of Giambattista Vico, argues that, as the Ili$a d$, the Divine Comedy represents an outstanding overview of his times ${ }^{22}$ :

Perhaps, there is no one among the great poets of the past except for Dante to whom this worn-out expression is attributed: he embodies all his times; there was no one, but Homer, who became the symbol of his century, of his peculiarities, of his genius and wisdom, as the great Florentine poet did. No Christian poet of the new era was more Christian than him, a son of this world who rises over the ruins of crumbled antiquity ${ }^{23}$.

The Polish writer considered Dante more of a realist with the Renaissance sensibility and propensity to present uncertainties and lively impressions with the use of his fertile imagination. Kraszewski, in his lectures, placed the origins of the European cultural revival in the 10th century as soon as Byzantine and Arab influences had wormed their way into Europe. Those led to the awakening of national self-consciousness and appearance of the first documents drawn up in national languages of France, Germany, England, Scandinavia and other European countries ${ }^{24}$. Indeed, the cultural development that reached its peak in the $13^{\text {th }}$ century stood out for its character and importance depending on the nation ${ }^{25}$.

After having introduced the most recurring features of all Dante's works, the author briefly explores Vita nuova ('The New Life'). Kraszewski, the same as Julian Klaczko, leans to the real existence of Beatrice ${ }^{26}$ : essentially, he would not accept an

22 I.K. Gorskij, op. cit., p. 38.

23 'Żadnemu może z wielkich poetów, przedstawicieli przeszłości, słuszniéj się nie należy jak Dantemu to nadużyte określenie - że sobą całą uosabia epokę; - żaden w istocie, prócz Homera, nie wcielił tak swego wieku, jego charakteru, jenijuszu i wiedzy, jak wielki wieszcz florencki - l'altissimo poeta. Żaden też z chrześciańskich poetów nowéj ery nie jest nadeń bardziéj chrześciańskim, wybitniéj synem tego świata, który na gruzach pokruszonéj starożytności się wznosi.' (J.I. Kraszewski, Dante. Studja, cit., p. 97).

24 I.K. Gorskij, op. cit., p. 39.

25 K. Morawski, La dantologia polacca moderna, "Beitræge zur romanischen Philologie" 1965, no. 2 (IV), pp. 94-95.

26 Ivi, p. 95. 
opinion of those who considered her a pure allegory, a mere fruit of Dante's imagination. Beatrice in the eyes of Kraszewski, became chiefly his muse of inspiration ${ }^{27}$ and played a role 'of the second master who, after Brunetto, taught him to suffer, to believe, to live with the light, spirit and $\mathrm{sky}^{2 \mathbf{2 8}}$. Subsequently, the author moves on to analyze woman's stil nuovo vision: poets stopped looking at her as 'humiliated bacchante' (upodlona bachantka) ${ }^{29}$, since the carnal passion had transformed into transcendent emotion; the woman was referred to as not only in terms of her material beauty, but also as an instrument of spiritual elevation. Kraszewski attributed this cultural deviation to the significant influence that Christianity assumed in the Medieval times. Moreover, he encompasses the relationship between angelic woman and the cult of holy Virgin Mary.

Simultaneously, the writer analyzes the artificiality of 'autobiography' described in the Commedia, that is to say a story narrated by Dante himself in order to name and to address the evils of the time in the plot.

The poet's biographic element was intended to serve in two ways: to make his journey to the afterlife be understood as real as well as to emphasize his genius adopted in the poetic field. Kraszewski rejected the positivist model typical for a psychologist portrait and explored the poem with the preference of romanticized vision with several references to Dante's biography. The underworld as a place of metaphysical experiences of the artist and intellectual at the same time truly represents a return to the real world ${ }^{30}$. In the Commedia the poet plays two roles: the one of a narrator who, at a later date, analyzes his journey to the underworld and the other of a poet and, at the same time, the main character of the poem who travels through the metaphysical world and experiences the feelings of pain and deprivation $^{31}$. Kraszewski takes into account even individual experiences and feelings that Dante knew and felt in the three underworld kingdoms: 'The major interest is focused on God and man; these are dramatis personae, the most important figures; all the rest is episodic and secondary'; 'here the main character is no semi-god, commander, king, city or state, he is just a poet, indeed, he is a man'32. Dante, therefore, expressed in his concerns the feeling of the whole humanity which is the real protagonist of the drama and this is where the Commedia focused its destinies

27 I.K. Gorskij, op. cit., p. 40.

28 'tego drugiego mistrza, co po Brunettim nauczyć go miał cierpiéć, wierzyć, żyć światłem, duchem, niebem' (J. I. Kraszewski, Dante. Studja, cit., p. 105).

29 Ivi, p. 106.

30 H. Bursztyńska, op. cit., p. 46.

31 Ibidem.

32 'Interes główny skupia się koło Boga i człowieka; to są dramatis personae, główne; reszta episodyczna i podrzędna' (J.I. Kraszewski, Dante. Studja, cit., p. 127); 'tu bohaterem jest nie pół-bóg, wódz, ani król, ani gród lub państwo, jest nim sam poeta, - mylę się, - jest nim człowiek' (ivi, p. 126). 
on. The fortunes of humankind represent the unity of action: 'The humankind, its fate, represented in Dante, are perceived according to the Christian idea ${ }^{33}$. Kraszewski legitimates the humanism of Dante mainly as the expression of Christian ethics: the poet did not introduce himself as a hero, but as an imperfect creature, who is weak, sinning and acknowledged his own mistakes and the same time suffering and continuously corrupted by $\sin ^{34}$.

The Polish author, when narrating one of the most profoundly touching episodes of the Divine Comedy, namely the story of Paolo and Francesca, reveals the human pathos of Dante: 'Truly, could it be anything more human than the compassion that the poet frequently manifests towards the damned in hell? He does not rail against the sentences that he felt were right, but the fate of those souls affects him until losing his minds. ${ }^{35}$ The language of the poem appears to be more natural in the moment when he describes human tragedies:

While often discussing theological and philosophical matters, Dante wanted to put into words a purely rational issue, as it was customary at that time, he played with words by selecting them, transforming into mosaic, giving a new, elegant meaning. However, when portraying a tragic fate of man, his passion, misfortune and weakness, he becomes a painter and creates pictures that remain deeply impressed for centuries in the minds of those who, at least once, had them in front of them. ${ }^{36}$

According to Kraszewski, Christianity has determined historical and cultural development and shaped that inner strength which is inherent in traditions and people of all ages. The author, thus, got closer to the Commedia with his idealistic concept of history postulating the certain victory of spirit over material forces. In the lectures on Dante there is already a germ of such historical vision which was subsequently considered by the author in more details in his aforementioned work, Polska w czasie trzech rozbiorów 1772-1799 (Poland of the time of the three partitions 1772-1799).

In a horrible Polish reality Dante's poem meant to many people an attempt to save themselves from desperation and to find an efficient way to escape from

33 'Ludzkość, jéj przeznaczenie, uosobione są w Dancie, pojęte wedle idei chrześcijańskiéj' (ibidem).

34 Ibidem.

35 'Zaprawdę, możeż być co bardziéj ludzkiego nad tę litość, którą poeta nie jeden raz okazuje w piekle dla potępionych? Nie złorzeczy on przeciwko wyrokowi Bożemu, czuje go sprawiedliwym, ale los tych dusz go przejmuje - aż do zmysłów utraty' (ivi, p. 137).

36 'Dante często w kwestijach teologicznych i filozoficznych, gdy mu przychodzi ująć w słowa temat czysto rozumowy, obyczajem wieku igra z wyrazy, dobiera je, bawi się niemi, układa je mozajkowo, nadaje im znaczenia różne, wykwintne; ale gdy maluje tragiczne losy człowieka, jego namiętności, niedolę, słabości, jest natchnionym malarzem, tworzącym obrazy, które na wieki wypiętnowane zostają w umyśle tych co je raz mieli przed sobą' (ibidem). 
a sad circumstances which Poland fell into after the failure of January insurrection of $1863^{37}$. Kraszewski, at some point, introduced the issue of exile by recounting Dante's vicissitudes and criticized those commentators who had speculated about the feeling of revenge in relation to Florence:

At the beginning, as every refugee, Dante did not imagine that returning home would be prohibited forever. Together with other fellows who were sentenced to exile, he wrote letters pleading for pardon, or rather for acquittal and return, as he promised to refrain from any hostile action towards his opponents, from any intrigue against the winning party ${ }^{38}$.

The author of Stara baśń, in contrast, observed Dante's patriotism right in the words of Cacciaguida:

You are to know the bitter taste of others' bread, how salt it is, and know how hard a path it is for one who goes descending and ascending others'stairs. ${ }^{39}$ (Par. XVII, 58-60)

Through the above-mentioned and many other extracts of the poem where the zeal for exile emerges clearly, the Polish writer learned the key to reading and understanding the poet's true love for his country. That love made Dante predict the sad prospect of the fall of Florence.

Subsequently, Kraszewski faces the language issue, stating that this is where the originality of Dante is expounded; the Tuscan dialect was raised to the rank of literary language, as a consequence of which it became a privileged instrument of poetic expression:

The language of the poem which Dante drew nearly unripe from people's lips and enhanced to such great perfection and no one's ever measured up in terms of style, echoes like a pleasant melody. It was the first time when Dante applied spoken Italian volgare, a language not fully consolidated until then, which struggled to be

37 I.K. Gorskij, op. cit., p. 46.

38 'W początkach, jak każdy tułacz, Dante nie przypuszczał, ażeby powrót do ojczyzny miał mu być na wieki wzbronionym. Wraz z innemi skazanemi na wygnanie pisał on listy błagające przebaczenia, domagające się raczéj usprawiedliwienia i powrotu, przyrzekając wstrzymać się od wszelkich kroków nieprzyjacielskich względem niechętnych, od wszelkich knowań przeciw zwycięzkiemu stronnictwu' (J.I. Kraszewski, Dante. Studja, cit., p. 113).

39 'Tu proverai sí come sa di sale, lo pane altrui, e come è duro calle, lo scendere e 'I salir per l'altrui scale' (Paradise, Canto XVII, lines 55-60, Allen Mandelbaum's translation, World of Dante, http://www.worldofdante.org/). 
adopted in written form in everyday life - and it was him to provide fixed forms aimed at further development ${ }^{40}$.

The writer also identified the value of the Divine Comedy in its ethical-moral aspects. The Dantesque experience consists essentially in urgency of moral reform of the world of the living: the poet is a real man, like Odysseus of the Christian Middle Ages who crossed the three after-world realms in order to lead the human race to salvation. Kraszewski, apart from giving a reintepretation of Dante's metaphorical journey through the prism of contingent reality, proved how the great Italian poet was inspired by ancient myths. It will suffice here to recall, by way of example, the Vision of Tundale that narrated journeys to the afterlife or to the unknown and distant lands ${ }^{41}$. The medieval inspiration did not exclude a true admiration for ancient culture with its most eminent representative in the person of Virgil. Kraszewski deepens the relationships between two poets and sheds light on the original idea according to which Dante made himself the author of Aeneid. His vision of the Latin poet was entirely independent from the legends widespread in the Middle Ages ${ }^{42}$.

The Polish critic, when presenting the political activity of Alighieri, argued with Cesare Balbo (1789-1853) and all those who accused the Florentine poet of versatility: '[he] turned out to be the greatest man of his century as well as of his contemporaries. He was neither Guelph nor Ghibelline, neither black nor white, he was just a loyal son of Florence who loved his country and wanted peace and harmony for it. ${ }^{33}$ The author of Studja considered such attitude as the proof of noble and independent spirit of the Florentine poet, therefore he reached out for salvation of Florence and he succeeded to find it 'neither in men nor in political parties, but in principles and ideals ${ }^{34}$. Moreover, if Dante had been not involved in political struggles - attributed with a huge historic importance by Kraszewski - the Divine Comedy would have never been born ${ }^{45}$.

The lectures of Kraszewski feature several controversial statements, for example the one concerning Dante's stays in Paris and in Oxford may be mentioned,

40 'Język poematu, który Dante wziął prawie surowym z ust ludu i do tak wielkiéj doskonałości wykształcił, iż po dziś dzień stylem mu nie zrównał nikt, brzmi jak melodija najwdzięczniejsza. Dante pierwszy nadał téj mowie włoskiéj, językowi dotąd jeszcze nieustalonemu, piśmiennie ledwie wschodzącemu w życie - stalsze formy, przez które daléj się miał kształcić' (ivi, p. 186).

41 K. Morawski, La dantologia polacca, cit., p. 95.

42 Ibidem.

43 'okazał się wyższym nad swój wiek i spółczesnych. Nie był ani gwelfem ani gibellinem, czarnym ani białym, był wiernem dziecięciem Florencyi, kochającym kraj, pragnącym dlań zgody i pokoju' (J.I. Kraszewski, Dante. Studja, cit., p. 109).

44 'nie w ludziach i stronnictwach, ale w zasadach i ideach' (ivi, p. 110).

45 I.K. Gorskij, op. cit., p. 41. 
which were regarded as hard evidential facts. While the trip to France was considered by many Dante's modern researchers probable, however all or almost all of them questioned the alleged period of studies in England. Kraszewski, who was convinced of his beliefs, analyzed the relationships of Dante with English culture and took for granted the impact of Roger Bacon on the author of the Commedia ${ }^{46}$. Albeit fully aware of the differences existing between the two authors, Kraszewski remained a very keen supporter of the theory of influence of the English scholar on Dante who, in his view, 'refers back to Bacon with almost the same vehemence, anger, indignation. ${ }^{.47}$ According to the author, the commentators of the Florentine poet always underestimated the probability of Dante's stay in Oxford as well as the consequences which could have resulted from it. It is likely that Dante right there got to know the manuscript of Opus Majus, the most famous scientific work of that time, and got inspired by it during the drafting of the Commedia ${ }^{48}$. Scartazzini severely criticized Kraszewski for the conviction of the latter who believed 'that Dante traveled to Oxford and the Malaspina's family provided him with the funds for getting there; that the poet got his whole inspiration from the knowledge of Opus Majus by Roger Bacon. The value of those and many other endless discoveries of this kind, is the fact that they are easily verifiable ${ }^{49}$. Moreover, the Swiss scholar of Dante biased against further information considered historically inaccurate such as actual existence of some persons given over misprints or weak quality of translation into German.

The defense of Kraszewski's theses was taken several years after by another critic Domenico Ciampoli, who was no Dante scholar, but expert of Slavic literatures. His opinion was fundamentally opposite to the one of Scartazzini, as he primarily rediscovered Kraszewski as a writer ${ }^{50}$ : 'In the novels and short stories Kraszewski was part of himself; he was a romantic who felt uncomfortable with educational

46 The critics of today do not exclude possible direct or indirect influence of Roger Bacon's thought on Dante, since Opus Majus was considered the most important scientific work. That is where the poet could borrow theories of optical science and others from (cf. S. Finazzi, La metafora scientifica e la rappresentazione della Corporeitas luminosa, in: La metafora in Dante, a cura di M. Ariani, Leo S. Olschki Editore, Firenze 2008, p. 190).

47 "powtarza Bacona prawie z tążsamą gwałtownością, gniewem, oburzeniem" (J.I. Kraszewski, Dante. Studja, cit., p. 116).

48 Ivi, p. 115.

49 'che Dante viaggiò a Oxford e che i Malaspina gli fornirono i mezzi onde fare il viaggio; che il poeta attinse tutta quanta la sua scienza dall'Opus Majus di Ruggero Bacone. II valore di queste e di infinite altre scoperte di tal natura si può facilmente indovinarlo' (A. Scartazzini, [rec.] Dante, Vorlesungen ueber die Goettliche Komoedie, gehalten in Krakau und Lemberg 1867 von J.I. Kraszewski. Ins Deutsche uebertragen von S. Bohdanowicz, Dresden Druk und Verlag von J.I. Kraszewski, 1870, "Nuova Antologia" 1871, vol. 17, pp. 524-526).

50 S. Piekut, Tematyka włoska w twórczości J.I. Kraszewskiego, "Oficyna Poetów" 1967, no. 3 (6), p. 36. 
divisions because he did not imitate anyone, and even if he did, he imitated people with the use of imitation that fosters recreation. The outstanding humanity of his characters reminds of our Manzoni's or Scott's ones... ${ }^{51}$.

Kraszewski's essay comprises of other position statements that Dante scholars consider exaggerated today: by way of example, I would like to mention a legend of Dante's unhappy marriage, where the author referred to the version provided by Boccaccio without putting it forward to any critical examination. However, there are also several insights preceding the current ones, for example: a refutable opinion about Dante's impact on 12th-century arts with particular regard to Giotto and his frescoes in the Scrovegni Chapel of Padua. According to Kraszewski, the fact of attributing the idea of Giotto's frescoes to Dante is erroneous: 'In the Divine Com$e d y$ written by Dante the poet's genius was set out in an impressive entirety, which is something that used to be vivid in the popular and church tradition. Giotto and Dante drew inspiration from the same source making use of the universal heritage, but without imitating each other. This is obviously where the similarities between them come from. ${ }^{, 52}$

The lectures are loaded with personal remarks made by the Polish Dante scholar; one of them to be mentioned is dedicated to the second canticle which is said to hold the primacy of beauty. Kraszewski considered the Purgatory the most fascinating and deserving admiration of the whole Commedia. As the author argues, the Florentine poet collected all the immensity of both his in-depth knowledge

51 "Nel romanzo, nella novella Kraszewski fece parte di se stesso; fu un romantico che sta a disagio tra le partizioni scolastiche, perché non imitò alcuno, o se imitò, imitò il popolo di quella imitazione che ricrea. La spiccata umanità dei suoi personaggi ricorda il nostro Manzoni o lo Scott..." (D. Ciampoli, Giuseppe Ignazio Kraszewski, "Studi Letterari" 1891, p. 41; lo stesso articolo è stato pubblicato su "Fanfulla della domenica" 1887, no. 15).

52 'W Boskiej komedii Dantego jeniusz poety złożył w potężną całość to, co naówczas żyło w tradycjach ludów i kościoła, Giotto i Dante czerpali z jednego źródła, nie zapożyczając się od siebie, biorąc ze skarbnicy ogólnej. Stąd naturalnie i podobieństwo ich obu.' (J.I. Kraszewski, Kartki z podróży 1858-1864 r. - Kraków, Wiedeń, Triest, Wenecja, Padwa, Medjolan, Genua, Piza, Florencja, Rzym, vol. I, Nakładem Gustawa Sennewalda, Warsaw 1866, pp. 180-181). Kraszewski, in fact, doubted that Dante might have influenced Giotto. Nowadays, the writer's assumption is endorsed by the critics, who consider their probable friendship and collaboration simply as mythical, since it is not supported by any written evidence (cf. A.F. De Carlo, Dramat w niebie i na ziemi. Kraszewski jako krytyk Giotta w Kartkach z podróży 1858-1864, in: Drogi i bezdroża komunikacji, P. Bering, G. Łukomski (eds.), Wyd. Kropka J. i W. Śliwczyńscy, Gniezno 2008, p. 189). One should not forget that they shared neither political ideals nor religious beliefs: for example, Dante was the enemy of almost all Giotto's contractors, including the pope Boniface VIII. It cannot be excluded that their meeting was held in Padua, where Dante went in exile, while Giotto was frescoing the Scrovegni Chapel: it is likely that those days there an exchange of ideas opinions between them actually took place (cf. Giotto. Compianto sul Cristo morto, a cura di F. Zeri, Rizzoli, Milano 1998, p. 17). 
and fertile imagination. While in Inferno the poet took inspiration from legends, myths and traditions, in Purgatory one meets men in their most terrestrial image where they are cleared and ennobled from all sins and mistakes they committed in lifetime. Moreover, the second canticle - according to Kraszewski - should convince that Dante was no political enemy to Catholic Church and the pope as long as: 'The purgatorial world is as if there was a life of the second stage of humanity; when being there, human feels a divine glimpse inside, their origins [...]; he is aware that he has to fight and win, since only by defeating the spirit, the body will be able to get closer to the divine model and to have the right to be reunited with the Lord. ${ }^{53}$

For Kraszewski, therefore, every canticle of the Divine Comedy may be associated with a given feature: 'Inferno is dominated by passion, Purgatory by feeling, Paradise by pure spirit. ${ }^{54}$ The writer borrows the ideas from Friedrich Schelling (1775-1854), who observed in his philosophical writings: Inferno is plastic and sculpture-like, Purgatory is painted and drawn, Paradise is musical because it is loaded with singing and melody. Kraszewski, by spreading the theories of Ozanam, which were also reviewed by Julian Klaczko in his renowned work Causeries Florentines, argued that Purgatory represented the most pleasant canticle of the whole poem: this is where the man meets creatures similar to the ones he knew in his earthly life. ${ }^{55}$ When in Inferno Dante suffers desperation of the condemned, in Purgatory he spots people hoping to atone for their sins.

Kraszewski, in the part dedicated to Purgatory, explained that Inferno has always been the canticle that fascinated his contemporaries: 'Dante is mostly known as the master of Inferno, only for a few as the poet of Paradise. ${ }^{.56}$ The Polish critic identified the main cause in the fact that the first canticle was more accessible to understand for an average reader, even though, according to the author himself, Purgatory and Paradise have nothing to envy to Inferno in terms of beauty and performance. Moreover, unlike Inferno and Paradise, the second canticle took little inspiration from legends and it is strictly connected with the image of the Earth, with the battles that purify the soul and ennoble it. In Purgatory there are fewer characters and everything is focused on the personality of the poet. Kraszewski

53 "Świat ten czyścowy to już jakby drugiéj epoki żywota ludzkości wizerunek; w nim człowiek uczuwa w sobie boską iskierkę, pochodzenie swe [...]; wie, że musi walczyć i dobijać się, aby duchem zwyciężając ciało do boskiego przybliżył się wzoru i z Bogiem miał prawo się połączyć" (J.I. Kraszewski, Dante. Studja, cit., p. 145).

54 "W Piekle panowała namiętność, w Czyścu znajdujemy uczucie, w Raju czystego ducha. Czyściec jest obrazem ziemi, na któréj walczym, nieustannie się oczyszczając, podnosząc, uszlachetniając" (ibidem).

55 M. Frąckiewicz, op. cit., pp. 37-38.

56 'Dante jest głównie znany jako malarz piekła, dla nie wielu jest wieszczem niebios' (J.I. Kraszewski, Dante. Studja, cit., p. 132). 
plunges together with Alighieri in this new world: 'Purgatory is more akin to the life on the earthly world [...], it boasts an exceptional beauty of an idealized image of our planet as well as of our lives.' ${ }^{37}$ The author clarifies this further on: 'In Purgatory we unite, through compassion, more closely to creatures that live in, who hold our weaknesses, we recognize ourselves in them, even if they are idealized. ${ }^{38}$ Kraszewski also disagrees with the aforementioned commentators on the fact that they have discovered a complete mystery in the symbolism of the poet. Although the Commedia is full of allegory, however - as stated by Kraszewski - it is not mysterious ${ }^{59}$. What is more, he argued with Rossetti and all the others who distinguished the apocalyptic tone in Dante's vision. ${ }^{60}$

The author also opposes to the opinions of all the commentators who saw Dante as the enemy of the pope and the Vatican. Alighieri was no opponent of papacy, he only reproached the Holy See for their interest of temporal power and material wealth ${ }^{61}$. The Church, instead of pursuing the aim of the soul salvation, concentrated only on earthly power, attempting to replace the emperor, but in doing so, it was just the chaos to arise and seeking earthly goods, at the same time, was corrupting. The lack of any top-down control contributes to the desire for money, a will to overpower one another outgrows and, finally, the conflicts among fractions and endless civil wars, which shed blood in the Italian towns, initiate. Dante opposed to that status quo, acting for the sake of the country and in accordance with the principles of justice. In this regard, the Polish writer felt spiritually very close to the Florentine poet, exactly in the same circumstances where he found himself labeled with anticlericalism.

The 'Titan of business' proved that the ruling classes mislead the Christian thought, once genuine and primordial. Such opinion explains, at first glance, a paradoxical fact that Kraszewski was said to gain bad reputation due to his uncompromising struggle against clerical reactionism. However, in the lectures on Dante he glorifies and idealizes Christianity by attributing to it the development of the whole human kind. That is why, when named Dante with the honor of 'the great poet', had in mind just the following idea: the author of the Comedy not only delivered the most ingenious synthesis of Middle Ages, but, on the other hand, he bridged the gap existing between the Middle Ages and Renaissance. Yet, he also opened a new era in the spiritual development of men. ${ }^{62}$

57 'Czyściec najbliższy życia i ziemi [...], ma niezrównany wdzięk wyidealizowanego świata naszego i naszego żywota.' (J.I. Kraszewski, Dante. Studja, cit., p. 147).

58 'W Czyścu współczuciem łączemy się bliżej z istotami zaludniającemi go, które mają słabości nasze, w których poznajemy samych siebie - choć podniesionych do ideału' (ibidem).

59 Ivi, p. 162.

60 I.K. Gorskij, op. cit., p. 47.

61 Ivi, p. 48.

62 Ivi, p. 39. 
The conclusion of the lectures of Kraszewski consists in an act of true reverence and respect towards the ingenious poet to whom the whole civilized world owes a lot. ${ }^{63}$ According to the writer, the Divine Comedy was born in the times when lots of truths were not uncovered yet and the legends played a relevant role ${ }^{64}$.The feelings and the concepts expressed in the Commedia can no longer be repeated the same as the work by Beato Angelico cannot be reproduced ${ }^{65}$.Thus, Dante's poem is unrepeatable and immortal, while its exceptional value, as Kraszewski wrote, is primarily seen in small things, in hand with the nature which is, as Latin proverb states, 'maxima miranda in minimis' (nature is the greatest in the smallest things). ${ }^{66}$

\section{IV}

The lectures on the Commedia of 1867, delivered by the writer to the institutions of Cracow and of Lviv, therefore, represent undoubtedly a significant contribution to the dissemination of Dante in Poland. This led to include Kraszewki in the rank of Polish and European Dante's researchers. Kalikst Morawski, an eminent romance philologist, emphasized, indeed, that Kraszewski may be inserted to the register of Polish Dante studies as the prime scholar expert next to Julian Klaczko.

Criticism towards Studja was never lacking and expressed by both compatriots and peers of Kraszewski, among whom Kazimierz Bogusławski was at the forefront. In his extensive essay titled Dante $w$ Polsce (Dante in Poland) the author stated that the studies of Kraszewski were devoid of scientific aptitude criticizing the lack of methods and qualifying the writer as an amateur. He considered the studies of Kraszewski interesting, though. The critic strongly disagrees with Kraszewski's essay labeling it as superficial for having neglected, following the works of Ozanam, Fauriel, Witte, Philalethes, Wegele, Blanc and Scartazzini, the most important moments of Dante's life which deeply affected his education and nourished his genius. Bogusławski complained about the lack of precision in describing the historical period the poet lived in. Subsequently, he mentioned the fact the author failed to deepen the rules which gave birth to such powerful creative strength and lavished affection. No scientific advice, which appears necessary for providing readers with a harmonious and uniform view, was highlighted, either. Furthermore, the critic pointed out the lack of discussion over issues which underlie the great poem: love, poetry, woman worship, the meaning of Beatrice and Virgil, sections dedicated to theology, philosophy, politics, cosmogony, history, astronomy etc. ${ }^{67}$. He briefly

\footnotetext{
63 K. Morawski, La dantologia polacca, cit., p. 96.

64 I.K. Gorskij, op. cit., p. 50.

65 Ibidem.

66 J.I. Kraszewski, Dante. Studja, cit., p. 143.

67 K. Bogusławski, Dante w Polsce, "Niwa" 1885, no. 260-261, p. 747.
} 
performed a broad analysis of Kraszewski's shortcomings confronting them with renowned Dante's researchers of that time. By way of example, the following extract may be quoted:

Kraszewski treats the meeting of Dante with Matelda equally in the final chants of Paradise, as well as the famous dialogue with Cacciaguida. [...] However, the author does not specify who this person was: a real person close to the poet, a personification of an idea, an allegorical figure or a historical character? And, yet, a lot has been written on this regard. At different times later, seven names of historical persons were mentioned to be seen under this figure. There were dozens of allegorical interpretations, too. ${ }^{68}$

On the other hand, Walerian Preisner, a librarian and a connoisseur of romance languages and literatures, considered the essay of Kraszewski, despite acknowledging a number of weaknesses and methodological shortcomings, not wholly 'superficial', and even less amateurish ${ }^{69}$. In general, it may be added that the criticism of Bogusławski addressed to Kraszewski remains questionable, since the writer proved to be thoroughly knowledgeable about Dante for his time. The lectures of the author of Stara baśń, indeed, have to be assessed in the proper time context: all the inaccuracies reported by Kraszewski are attributable to the interpretations of Dantes's poem which were floating around, to the imprecise instruments as well as to the limited information that the researcher had at his disposal. The lectures of Kraszewski, despite being considered inadequate in certain places, got credit to disseminate Dante in Poland ${ }^{70}$. In fact, interpretation attempts and biographical information represented a stimulus for reading and for popularization of the Commedia to a wider public.

Considering the above, the studies on the Divine Comedy by Kraszewski (Studja nad Komedja Boska) represented not only a significant contribution to the dissemination of the genius of the Italian poet as well as of the Divine Comedy in Poland, but also a valid input towards progress and development of Dante studies in Poland.

\section{Translated from Italian by Łukasz Jan Berezowski}

\footnotetext{
68 'Podobnie jak końcowe pieśni Raju, lub słynną rozmowę Cacciaguidy, traktuje Kraszewski spotkanie Danta z Matyldą. [...] Autor nie podaje nawet, kimby ta postać była: czy osobą rzeczywistą z otoczenia poety, czy personifikacyą jakiej idei, czy postacią alegoryczną, czy z dziejów wziętą? A przecieżw przedmiocie tym pisano nie mało. Podawano różniej czasy aż siedm osób historycznych, które chciano widzieć pod tą postacią. Było też kilkanaście interpretacyj alegorycznych' (ivi, p. 752).

69 W. Preisner, Dante i jego dzieła w Polsce. Bibliografia krytyczna z historycznym wstępem: I. Stan badań nad Dantem w Polsce; II. Próba polskiej bibliografii dantejskiej / Dante e le sue opere in Polonia. Bibliografia critica con una introduzione storica: I. Gli studi danteschi in Polonia; II. Saggio d'una bibliografia dantesca polacca, PWN, Toruń 1957, p. 57. Ivi, p. 55.
} 


\section{Bibliography}

Biliński Bronisław, Incontri polacco-italiani a Porta Pia: J.I. Kraszewski, W. Kulczycki, M. Konopnicka. Nel centenario di Roma capitale d'Italia 1870-1970, Wyd. PAN, Wrocław-Warsaw-Cracow-Gdańsk 1971.

Biliński Bronisław, Roma antica e moderna nelle opere di Giuseppe Ignazio Kraszewski, Wyd. PAN, Wrocław-Warsaw-Cracow 1965.

Bursztyńska Halina, Kraszewski Orzeszkowa Sienkiewicz. Studia i szkice, Wyd. Naukowe WSP, Cracow 1998.

De Carlo Andrea Fernando, Dramat w niebie i na ziemi. Kraszewski jako krytyk Giotta w Kartkach z podróży 1858-1864, in: Drogi i bezdroża komunikacji, Piotr Bering, Grzegorz Łukomski (eds.), Wyd. Kropka J. i W. Śliwczyńscy, Gniezno 2008, pp. $185-195$.

De Carlo Andrea Fernando, La Divina Commedia nella Polonia del XIX secolo. Le prime traduzioni polacche del poema dantesco a confronto, in: Il Dante dei moderni. La Commedia dall'Ottocento a oggi. Saggi critici, a cura di Joanna Szymanowska, Izabela Napiórkowska, LoGisma, Firenze 2017, pp. 125-144.

De Carlo Andrea Fernando, Między piektem a niebem. Postrzeganie Boskiej Komedii Dantego przez Zygmunta Krasińskiego i Józefa Ignacego Kraszewskiego, in: Krasiński i Kraszewski wobec europejskiego romantyzmu i dylematów XIX wieku. Wdwustulecie urodzin pisarzy, Maciej Junkiert, Wiesław Ratajczak, Tomasz Sobieraj (eds.), Wyd. Poznańskiego Towarzystwa Przyjaciół Nauk, Poznań 2016, pp. 33-45.

De Carlo Andrea Fernando, O specyfice języka J.I. Kraszewskiego w rękopisie zawierajacym tlumaczenie Boskiej Komedii Dantego, in: Kraszewski i wiek XIX. Studia, idea and layout Jarosław Ławski; Anna Janicka, Krzysztof Czajkowski, Paweł Kuciński (eds.), Książnica Podlaska im. Łukasza Górnickiego, Katedra Badań Filologicznych „Wschód-Zachód”, Wydział Filologiczny Uniwersytetu w Białymstoku, Białystok 2014, pp. 291-309.

Frąckiewicz Michał, Józef Ignacy Kraszewski w Krakowie i we Lwowie w r. 1867 i odczyty jego o Dantem. Wspomnienia z przeszłości w setna rocznicę urodzin, Nakładem Autora, Cracow 1912.

Giotto. Compianto sul Cristo morto, a cura di Federico Zeri, Rizzoli, Milano 1998.

Gorskij Ivan K., Крашевскийи Данте, “Дантовские чтения” 1968, pp. 33-52.

Kraszewski Józef Ignacy, Dante (z odczytów J.I. Kraszewskiego 1867 r.), in: Kłosy i kwiaty. Ksiażka zbiorowa w Krakowie, W Drukarni W. Kirchmayera, Cracow 1869, pp. 67-97.

Kraszewski Józef Ignacy, Dante. Studja nad Komedja Bozka przez J.I. Kraszewskiego, "Roczniki Towarzystwa Przyjaciół Nauk Poznańskiego" 1869, vol. V, p. 95-189.

Kraszewski Józef Ignacy, Dante. Vorlesungen ueber die Goettliche Komoedie Gehalten in Krakau und Lemberg 1867 von J.I. Kraszewski. Ins Deutsche uebertragen von S. Bohdanowicz, Druk und Verlag von J.I. Kraszewski, Dresden 1870. 
Kraszewski Józef Ignacy, Pamiętniki, Wincenty Danek (ed.), Ossolineum, Wrocław $1972^{4}$.

La metafora in Dante, a cura di Marco Ariani, Leo S. Olschki Editore, Firenze 2008. Morawski Kalikst, La dantologia polacca moderna, "Beitræge zur romanischen Philologie” 1965, no. 2 (IV), pp. 90-97.

Płaszczewska Olga, „Onorate l’altissimo poeta”: Józef Ignacy Kraszewski jako komentator Dantego, in: Kraszewski: poeta i światy. Tadeusz Budrewicz, Ewa Ihnatowicz, Ewa Owczarz (eds.), Wyd. UMK, Toruń 2012, pp. 191-203.

Preisner Walerian, Dante i jego dzieła w Polsce. Bibliografia krytyczna z historycznym wstępem: I. Stan badań nad Dantem w Polsce; II. Próba polskiej bibliografii dantejskiej / Dante e le sue opere in Polonia. Bibliografia critica con una introduzione storica: I. Gli studi danteschi in Polonia; II. Saggio d'una bibliografia dantesca polacca, PWN, Toruń 1957.

Scartazzini Andrea Giovanni, [review] Dante, Vorlesungen ueber die Goettliche Komoedie, gehalten in Krakau und Lemberg 1867 von J.I. Kraszewski. Ins Deutsche uebertragen von S. Bohdanowicz, Dresden Druk und Verlag von J.I. Kraszewski, 1870, "Nuova Antologia" 1871, vol. 17, pp. 524-526.

Andrea F. De Carlo

\section{"Uczcijcie nąjwiększego poetę" Wkład Józefa Ignacego Kraszewskiego w rozwój polskiej dantologii}

\section{Streszczenie}

Artykuł przedstawia wkład Józefa Ignacego Kraszewskiego w rozwój polskiej dantologii. Działo się to za sprawą lekcji, które Kraszewski prowadził na temat Dantego w Krakowie i Lwowie w 1867 roku, które następnie, w roku 1869, ukazały się drukiem pod tytułem: Studja nad Komedja Boska. W artykule zaprezentowano inne ówczesne opinie badaczy-dantystów oraz mniej lub bardziej krytyczne recenzje wyników badań Kraszewskiego.

Słowa kluczowe: Polska dantologia, Józef Ignacy Kraszewski, Dante Alighieri, Studja nad Komedja Boska 


\title{
"Honor the great poet" The Józef Ignacy Kraszewski's contribution to the development of Polish Dante studies
}

\author{
Summary
}

The article analyses the Józef Ignacy Kraszewski’s contribution to the development of Dante studies in Poland. It was thanks to his lectures on Dante, held in Krakow and Lviv in 1867, and later published under the title Studies on The Divine Comedy, 1869. The article presents other opinions of Dante scholars of the time and more or less critical reviews of the results of Kraszewski's research.

Keywords: Polish Dante's studies, Józef Ignacy Kraszewski, Dante Alighieri, Studies on The Divine Comedy

Andrea Fernando De Carlo, teaches Polish Language and Literature at the University of Naples "L'Orientale". He received his PhD from the University of Salento with a thesis on Dante in 19th-century Poland (a comparison between the different translations of The Divine Comedy by Kraszewski, Korsak, Stanisławski and Porębowicz). His research interests include Polish literature, cultural relationships between Italy and Poland, and poetic translation. His publications appear in several Polish and Italian academic journals.

Andrea Fernando De Carlo, prof., Dipartimento di Studi Letterari, Linguistici e Comparati, Język i Literatura Polska, Università degli Studi di Napoli „L'Orientale", Neapol, Włochy. Od 2006 do 2011 roku był profesorem kontraktowym na Wydziale Języków i Literatury Obcej przy Uniwersytecie Salento w Lecce (Włochy), gdzie prowadził zajęcia z literatury, tłumaczeń i języka polskiego. Od 2011 roku wykłada język i literaturę polską na Uniwersytecie „L'Orientale” w Neapolu. W swojej pracy naukowej koncentruje się głównie na trzech obszarach badawczych: włosko-polskich związkach literackich, tłumaczeniach poetyckich oraz krytyce tekstów. Wyniki swoich badań publikuje w czasopismach i periodykach włoskich i zagranicznych. Jednym z najnowszych jego opracowań jest projekt badawczy - analiza przekładu Boskiej Komedii Dantego w wykonaniu Józefa Ignacego Kraszewskiego. 